\title{
'Sanctifying Sex': Exploring 'Indecent' Sexual Imagery in Pentecostal Liturgical Practices
}

\author{
Sarojini Nadar ${ }^{1}$ and Johnathan Jodamus ${ }^{2}$ \\ snadar@uwc.ac.za \\ jjodamus@uwc.ac.za
}

\begin{abstract}
Pentecostalism, like many other church traditions, is well known for its fixation with doctrinal dualisms which enforce a separation of body and spirit, and a Puritan sexual ethic. These conservative sexual norms have led to the policing of bodies and sexual practices. As a result, instead of encouraging safer sexual practices, the churches have been known to enforce abstinence outside of marriage, or sexual restrictions within it, thus marking sex in general as 'indecent'. Some of the consequences of this repression of sexuality are young people being forced into early marriages to avoid 'living in sin', teenage pregnancies as a consequence of not wanting to disobey the church's teaching on sex and contraceptives, as well as more serious consequences of unbridled sexual expressions resulting in sexually transmitted viruses. The consequences of a repressed sexuality are indeed serious. However, what if this 'repressive
\end{abstract}

1 Sarojini Nadar (PhD) holds the Desmond Tutu South African Research Chair (SARChI) in Religion and Social Justice at the University of the Western Cape. Her research is broadly located at the intersections of gender studies and religion, including gender-based violence, sexual and reproductive health rights, and critical pedagogy in higher education. This article is based on research supported by the National Research Foundation of South Africa (Grant number: 118854). The authors acknowledge that opinions, findings, and conclusions expressed are those of the authors alone, while the NRF accepts no liability whatsoever in this regard.

2 Johnathan Jodamus (PhD) is a lecturer at the University of the Western Cape. His research and teaching are interdisciplinary, focusing on gender studies and biblical studies. More recently, he has developed a wider research interest in how religion shapes and is shaped by gender, race, and sexuality. 
hypothesis' can be challenged within Pentecostal spaces? What if, like Foucault suggests, a deeper engagement with the subject matter would show, not sexual censorship, but rather a re-channeling of sexuality? Drawing on Foucault's challenge to the repressive hypothesis, where he suggests that socalled repressed sexuality finds 'appropriate' outlets in spaces such as psychiatry and prostitution, this essay suggests a third outlet, namely Pentecostalism. While particular sexual discourses may be constructed as indecent and contaminated as 'sin', liturgical and deliverance practices ironically signify erotic relationships between the divine and the believer. Proceeding with an 'indecent' theological lens, as proposed by Marcella Althaus-Reid, we argue that Pentecostalism's liturgical practices ironically and unconsciously open up possibilities for more embodied, real, and sexed experiences of the divine. This consideration not only expands the interpretive possibilities for how we mark relationships with the divine, but also how sexual relationships between humans are shaped and possibly destigmatized. In taking a sneak peek 'under God's skirt', in Althaus-Reid's words, we reimagine the indecent as sacred. Through an analysis of how bodies and rituals are marked by discursive practices within the songs and performances in these churches and an examination of a blasphemy case, this essay lays bare the critical spaces available for more embodied theologies - 'sexual healing' that perhaps even the worshipers themselves have unconsciously ignored.

Keywords: Pentecostalism, sexuality, indecent theologies, embodiment, Foucault

\section{Background}

In a conversation over coffee some time ago, we pursued a rather animated discussion focused on our lived experiences in two major Pentecostal denominations in South Africa. While each of us grew up in Apartheid South Africa in different contexts from each other - Johnathan in Mitchells Plain on the Cape Flats ${ }^{3}$ in the Assemblies of God church, and Sarojini in an Indian

3 The Cape Flats is an Apartheid designation that is commonly used to describe the areas that people of color were relocated to when race-based legislation allowed the bulldozing of people's homes and the reallocation of those prime lands to White 
township ${ }^{4}$ known as Phoenix in the Full Gospel Church in Durban. We shared a common experience in terms of Pentecostal liturgical practices - particularly the singing (praise and worship) and deliverance (altar calls for salvation and healing) aspects. Our conversation led to the same conclusion in each of our cases - that is, when it comes to matters of sexuality in the Pentecostal churches in which we grew up, the defining characteristic is 'restriction'. The list of 'thou shalt not's' and restrictions that came through in the churches' teachings on sex, often left us with feelings of shame, sinfulness, and repression. And yet we recognized that while the teachings fostered and promoted restriction and repression, sex resurfaced and rematerialized in other spaces - most perceptibly in the singing and deliverance aspects of the service. This recognition of expressions of sexuality, rather than repressions of it, found resonance with Foucauldian $^{5}$ theoretical explanations emerging from our collective experiences within the church.

Using a notion of power as developed by Foucault (1980b; 1997c:163173), this essay sets out to examine how Pentecostal churches' praise and worship practices manifest embodied discursive performances of repressed sexuality $^{6}$, the charismatic outpouring, climaxing with the crescendo of orgasmic ritual performances and healing of souls. In these contexts, liturgical practices are important conduits that ultimately seemingly usher in the Spirit and power - power as productive and not repressive (Foucault 1982:208-226),

people. The Cape Flats, also known in Afrikaans as 'Die Kaapse Vlakte', signifies displacement.

4 Townships like the Cape Flats were also areas that were 'allocated' to people of color. These areas were largely undeveloped and reserved for 'non-whites' - classified as Indian, African, and 'Colored' people. They were usually built on the edges of urban South Africa.

5 This designates the work and theories as posited by Foucault.

6 The understanding of discourse in this regard is premised on Michel Foucault's Two lectures (Foucault 1980a:93). He states that '[w]hat I mean is this: in a society such as ours, but basically in any society, there are manifold relations of power which permeate, characterise and constitute the social body, and these relations of power cannot themselves be established, consolidated nor implemented without the production, accumulation, circulation and functioning of a discourse. There can be no possible exercise of power without a certain economy of discourses of truth which operates through and on the basis of this association'. 
not located in subjects or the Subject, but at work in discursive practices and even ritual performances.

Foucault's challenge to the theory of repressive sexuality, where he proposes that sexuality was not as repressed as claimed, but instead found 'appropriate' outlets, is instructive for this essay. Foucault (1985:4) suggests that, from the $17^{\text {th }}$ to the $20^{\text {th }}$ century, the main outlets for sexuality was institutionalization (psychiatry) or criminalization (prostitution). This essay explores a contemporary third 'outlet' - spiritualization (Pentecostalism). This consideration expands the interpretive possibilities for Foucault's analysis. He explains it as follows:

We must therefore abandon the hypothesis that modern industrial societies ushered in an age of increased sexual repression. We have not only witnessed a visible explosion of unorthodox sexualities; but - and this is the important point - a deployment quite different from the law, even if it is locally dependent on procedures of prohibition, has ensured, through a network of interconnecting mechanisms, the proliferation of specific pleasures and multiplication of disparate sexualities (Foucault 1978:49).

In this essay we explore one of these 'proliferation of specific pleasures' as an expression of sexual pleasure via the discourses of sexuality, expressed through the liturgies within the Pentecostal church. Through a critical discourse analysis of the lyrics found in selected praise and worship choruses and songs, this essay explores to what extent these songs allow for the expression of repressed sexuality that is ostensibly strict and doctrinally controlled in these churches. It calls for the consideration that these songs actually open up critical spaces for more embodied theologies - sexual healing that perhaps even the worshipers themselves have unconsciously ignored.

Therefore, what initially began as a frivolous flirtation with the ways in which the "sexual sung syntax" in our Pentecostal churches reflects an outlet for a repressed sexuality, has evolved into this essay which attempts to offer a more serious and daring engagement with the phenomenon of such singing and

7 We are grateful to a colleague, Patrick Pillay, for his conceptualization of the notion of a 'sexual sung syntax'. We have developed the idea further through discourse analysis - focusing on syntax, semiotics, and semantics. 
other performances in these churches. Before we explicate this notion of a sexual sung syntax, it is important to first sketch the Puritan sexual ethic which governed and, to a large extent, still governs Pentecostal theologies.

\section{Puritan Pentecostal Sexual Ethics}

Both our Pentecostal churches - the Assemblies of God and the Full Gospel Church of God - trace their origins to the 1906 'Azusa Street' revival, started by the African-American evangelist William J. Seymour (cf. Creech 1996:405424; Anderson 2005:175-185) ${ }^{8}$. We acknowledge the diversity of expressions within the Pentecostalism, ranging from the classical Pentecostals to the megachurch phenomenon and, most recently, the apostolic revival (cf. Anderson 2013). While many of these groups differ slightly in terms of their doctrines, the singing and deliverance aspects of the services remain largely comparable across the spectrum (cf. Phillips \& Riches 2018:1-3). Therefore, this essay focuses on the origins of all the various sects within Pentecostalism, dating back to the Azusa Street revival, also known as the Holiness movement. Our interest in the Holiness movement is in how it controls matters of sexual ethics and morals - abstinence outside of wedlock and restriction within it $^{9}$. The Holiness movements of the early $20^{\text {th }}$ Century were explicit in their teachings about the distinction between matters of the flesh and higher callings of the spirit. To reach higher spiritual heights, one had to abandon the desires of the flesh - and so, while sexual desire was tolerated, it (or anything related such as social dancing and fashion) was not the focus - it had to be repressed and restricted. Frederick Ware notes:

8 Creech (1996:405-424) argues that while many church historians trace the source of all Pentecostal denominations to Azusa, he warns of being careful not to homogenize the movement and to be aware of subtle nuances. Ogbu Kalu also cautions that attributing Pentecostalism in Africa solely to its American origins, neglects the indigeneity which characterizes much of the practice of Pentecostalism (Kalu 2009:71-90). While we agree with these various voices of caution, we speak here of the similarities that we detect in the practices regarding 'holiness' without necessarily abandoning an appreciation for indigenous forms of spirituality, nor the binaries that are created by colonial forms of scholarship. As Achille Mbembe reminds us, these 'facts' are always 'entangled' (Mbembe 2001:1-14).

9 This tradition of sexual restriction continues into the $21^{\text {st }}$ century in South Africa as research by Burchardt (2011:669-683) and others indicate. 
Pentecostals have invested the greater sum of their energy in combating perceived personal sins such as social dancing, styles of clothing (mostly women's fashions), lipstick and cosmetics, the use of tobacco products (cigars, cigarettes, snuff, chewing tobacco), alcoholic beverages, narcotics, gambling, premarital and extramarital sex, divorce, homosexuality, and same-sex marriage (Ware 2011:199-200).

The challenges posed by the struggle between the flesh and the spirit in the Pentecostal spirituality comes into sharp focus in a book chapter by Louis Gallien Jr. where he explores the life of three 'soul' artists who grappled with reconciling what he calls, their Pentecostal cultural beliefs, with their 'desires of the flesh' (Gallien 2011:131).

Gallien focuses on the three secular music icons with deep roots in African-American Pentecostalism: Sam Cooke, Marvin Gaye, and Donny Hathaway. Of the three artists whom he explores, the narrative of Marvin Gaye is of interest for this essay for the ways in which it sheds light on the themes of sexuality and spirituality within the Holiness movements. Gallien notes the following:

Gaye was caught up in two problematic dimensions of his background: his church and his father. Regarding his church background, Gaye was constantly looking for either a détente with, or an avenue toward a sanctified sexuality. As he struggled between his legalistic background and his hedonistic lifestyle on the road, Gaye sought to find a way to integrate his almost insatiable need for sex with his equally emotional need for God. In essence, he was looking for an honest and transparent spiritual life that acknowledged the lust of the flesh with the need for forgiveness. What Gaye sought was not possible in a sanctified Pentecostal church (Gallien 2011:130).

While Gallien sees Gaye as a compulsory 'crossover artist', that is an artist who has to 'crossover' to the secular because of being unable to reconcile the sacred and the sexual, we contend, drawing on Foucault's challenge to the repressive hypothesis, that a careful analysis of Marvin Gaye's songs reveals a seamless integration of spirituality and sexuality, rather than the disjuncture that Gallien claims. A few verses of the lyrics of Let's get it on make the point most clearly (Gaye \& Townsend 1973): 


\section{Let's get it on}

You don't have to worry that it's wrong If the spirit moves you, let me groove you

Good, let your love come down, oh Get it on, come on baby, do you know I mean it

I've been sanctified, hey hey

Girl you give me good feelings, so good

Somethin' like summer time.

In extending the sexual invitation in this song, Gaye actually appropriates Pentecostal religious language and claims that he has been sanctified, and that it is this 'sanctification' that justifies the sexual invitation. The irony is that, despite the Puritan Pentecostal sexual ethic, which Gallien claims, makes it compulsory for Marvin Gaye to 'crossover' to the secular, it is clear that the 'sanctification' follows Gaye into this particular song. This traffic from the sacred to the secular is certainly not one-way, we would argue, and we suggest that the same 'syntax' that is used in the rhythm and blues songs sung by Gaye and more contemporary artists, finds its way into the church through what is called above, 'a sexual sung syntax'.

\section{Exploring a Sexual Sung Syntax}

A sexual sung syntax emerges specifically in these Holiness movements that lay claim to a body/spirit dualism. An explication of the concept deserves some attention here. Drawing on the way in which syntax is used to explain linguistic structures in language discourse, we use syntax here to describe the structures of music that are shared between two genres: Gospel and rhythm and blues (R\&B).

Consider the syntax between three worship songs, famous in the Pentecostal churches: The first is a hymn written by Bill Gaither in 1963 and taken to its ultimate fame by Elvis Presley (who himself was raised in a Pentecostal church) on his Grammy award-winning album of the same title in 1971, He touched me. The second is a more contemporary song, The power of your love and the third is Your love is extravagant by Casting Crowns. 
The first song, He touched me, while originally sung in most classical Pentecostal churches as a full hymn, later evolved into a famous worship chorus, focusing on the words 'he touched me' (Gaither 1963):

\section{He touched me}

Shackled by a heavy burden,

'Neath a load of guilt and shame.

Then the hand of Jesus touched me, And now I am no longer the same.

He touched me, Oh He touched me, And oh the joy that floods my soul! Something happened and now I know, He touched me and made me whole.

Since I met this blessed Savior, Since He cleansed and made me whole,

I will never cease to praise Him,

I'll shout it while eternity rolls.

He touched me, Oh He touched me, And oh the joy that floods my soul!

Something happened and now I know He touched me and made me whole.

While this song has similarities in terms of the lyrics with secular R\&B, it still maintains a degree of the hymn-like structure. As Pentecostalism develops, however, we find that both the lyrics and the structure have followed an explicit $\mathrm{R} \& \mathrm{~B}$ structure, while losing much of the 'hymn-like' structure. The song, Power of your love, even shares a title with R\&B artist, Celine Dion's song: 
The power of your love

Lord I come to You

Let my heart be changed, renewed

Flowing from the grace

That I've found in You

Lord I've come to know

The weaknesses I see in me

Will be stripped away

By the power of Your love

Hold me close

Let Your love surround me

Bring me near

Draw me to Your side

And as I wait

I'll rise up like the eagle

And I will soar with You

Your Spirit leads me on

In the power of Your love

Lord unveil my eyes

Let me see You face to face

The knowledge of Your love

As You live in me

Lord renew my mind

As Your will unfolds in my life

In living everyday

By the power of Your love

(Fragar, Bullock \& Zschech 1992).

The next worship song, Your love is extravagant, moves completely into the 'love song' genre, describing intimacy between the believer and the divine in ways that are nothing short of sexual: 


\section{Your love is extravagant}

Your love is extravagant

Your friendship, it is intimate

I feel like moving to the rhythm of Your grace

Your fragrance is intoxicating in our secret place

Your love is extravagant

Spread wide in the arms of Christ is the love that covers sin

No greater love have I ever known

You considered me a friend

Capture my heart again

(Casting Crowns 2003).

The shared sexual sung syntax between secular R\&B music and the more contemporary praise and worship songs is stark. An analysis of syntax restricts our discussion to the level of structure, but what is distinctive about Pentecostalism cannot be limited to structure. If we wish to understand the phenomenon on a deeper level, an examination of performance is necessary. Therefore, we move from syntax to semantics - the study of meaning - because the symbols and the signs present in the sexual syntax obtain its meaning through performance.

\section{Sexual Semantics}

The idea of repressed sexualities, as articulated by Foucault, cannot be read in isolation from his broader themes of inquiry. The themes of subject, discourse, and power are central to Foucault's work, where he challenges the stability of the individual subject. Foucault argues further that one can find different types of 'techniques of the self' in specific historical and cultural situations, so that different types of subjects are constituted from different historical and social configurations (Foucault 1997a; 1997b:224-225). He argues,

The individual is not to be conceived as a sort of elementary nucleus, a primitive atom, a multiple and inert material on which power comes to fasten or against which it happens to strike, and in so doing subdues or crushes individuals. In fact, it is already one of the prime effects of 
power that certain bodies, certain gestures, certain discourses, certain desires, come to be identified and constituted as individuals (Foucault 1980a:98).

Thus, rather than seeing individuals as stable entities, he analyzes the discursive processes through which bodies are constituted and maintains that the body is the site on which multiple discourses are enacted and where they are contested (Foucault 1980a:93-94, 97).

To illustrate our point, we attempt to offer a thick description of the performances of the believers (the Pentecostal subject) during the deliverance part of a typical Pentecostal service in an Indian township known as Chatsworth in Durban. We analyze a visual recording of the service to explore the various 'discursive processes through which bodies are constituted' to express sexuality in a seemingly repressive environment (Bethesda Worship Centre 2017).

In this video (starting at 2:52 on the video timeline) the believers, made up largely of women, stand before a pastor who is praying for their deliverance (Bethesda Worship Centre 2017). The mostly female believers have their eyes tightly closed, while they rock backwards and forwards, some with tears streaming down their faces, others shaking their raised hands, and moving their bodies in rhythmic gyrations, all the time calling out to Jesus, some articulating the words 'come Lord Jesus', while the pastor 'touches' each of them with a cloth, calling on Jesus to touch them, and for them to 'receive'. As the music reaches a climax, and the pastor's praying gets more fervent, the women start to fall to the ground - the (mostly male) ushers are on hand, ready to cover them with blankets that seem to be especially made with the branding of this particular church. The scene ends with rows of believers lying on the floor covered in blankets, after a seemingly satisfactory encounter with Jesus.

In this video the sexual overtones are stark! We encounter the foreplay in the ritual singing of the songs - the lyrics dripping with sexual innuendo, while the deliverance part of the service, or the altar call, offers the climax culminating in the orgasmic performances - even ending with the blankets that the ushers cover the believers with. One could argue that the only thing that is missing is the post-coital cigarette!

In summary, through an examination of the sexual sung syntax (the lyrical structure of the praise and worship songs sung in Pentecostal churches) and the sexually charged performances by which the songs find its physical 
expression (a sexual semantic), one could argue that we have engaged in a project of 'indecenting'. While Althaus-Reid uses the term to challenge liberation theologians to recognize the interconnections between sex (not just gender) and class (and to a lesser extent race), she also uses the term to indicate that all theology 'is a sexual act. Theology is a sexual ideology performed in a sacralising pattern: it is a sexual divinised orthodoxy (right sexual dogma) and orthopraxy (right sexual behaviour); theology is a sexual action' (Althaus-Reid 2000:87).

What we have shown thus far is that Pentecostal sexual orthodoxy and Pentecostal sexual orthopraxy meet at the crossroads of a liturgical discursive practice - singing and deliverance. While this point seems clear enough from the foregoing descriptions, Gallien notes the difficulties that such an analysis poses, and points to the fact that, despite the ways in which Michael Dyson and others have challenged 'the black church' to embrace sexuality as a gift, a holistic form of spirituality seems to be jettisoned in favor of dualisms. Gallien notes:

As Dyson points out, the attraction of black Holiness-Pentecostal services are the degree to which they differ from the more staid forms of worship in non-Pentecostal churches since so much of their services are dedicated toward integrating the physical with the spirit that results in their whole bodies and souls belonging to the Lord. While Dyson views such services through erotic and sexually charged lenses, the Holiness-Pentecostal churches eschew any idea that their services are deliberately erotic or can or should be evaluated from that perspective. As a result, Dyson's call for a theology of the erotic in these churches has received little response (Gallien 2011:135).

\section{Erotic Theology}

The call for a 'theology of the erotic' has been made by scholars such as Adriaan van Klinken and Keri Day, in different contexts ${ }^{10}$. We would argue

10 Van Klinken (2018:13) destabilizes the 'popular Christian politics of sexual citizenship in Africa that restrict romantic and erotic love to the context of heterosexual marriage'. Similarly, and drawing on the work of black feminists, Day 
that not only have calls for a more erotic theology been ignored, but they have been outright refuted, and even called blasphemous. An example of a case in South Africa, brought by a pastor to the Broadcasting Complaints Commission (BCCSA) regarding a scene in a TV series called Californication, illustrates this point (Californication 2016). The scene involves a dream sequence where a young woman walks into a church, with a bottle of alcohol in one hand and a cigarette in the other. She starts talking to a statue of Jesus hanging on a cross. To her surprise, he opens his eyes and starts speaking to her. She immediately apologizes. He responds, 'What can I do for you?' She answers, 'I miss you, I need you. Especially right now. I'm having what you might call a crisis of faith'. Jesus responds by asking her to pray, and she begins, 'Forgive me Father for I have sinned', to which he laughingly retorts, 'You think?', and then starts pulling the nails off his hands and disembarking from the cross. The young woman nervously reacts, saying, 'Jesus, no need to get your loin-cloth in a knot', but it is too late, as Jesus is already off the cross and approaching her. He says, taking a drag of her cigarette, 'I think you're forgetting something... Jesus loves you', and then passionately kisses her. At this point, she awakes from her dream.

One might argue that the kind of erotic theology that is present in this dream sequence is a logical conclusion to the kinds of songs and performances present within the Pentecostal liturgical practice - not according to the pastor who lodges a complaint with the BCCSA. The BCCSA (2015) documents the complaint and the response as follows:

Complainant:

I would like to lodge a complaint regarding the above programme. It depicted a scene (where the lady was dreaming) but visibly showing that Jesus was on the cross crucified, and then got off the cross, hugging the young lady and stating Jesus loves you, albeit in a sexual manner, since he wants to kiss the young lady. This is unacceptable, since the idea is to connote that Jesus wants to have a sexual relationship with the young lady, whether a dream state or not. This can be defined as being blasphemy. Artistic licence is one thing but blasphemy something else. In my view the Broadcaster has crossed the

argues for a recovery of the erotic as a reflection of self-expression and connection, rather than repression and disconnection (Day 2016:77-104). 
line, and according to our constitution this is not acceptable. I humbly request that you render a decision on this matter.

The BCCSA dismissed the complaint, stating:

1. The episode in question, which was shown in the watershed period, had an audio advisory and 18LNP on screen at the start of the programme and after each ad break.

2. The scene complained about was a dream sequence in which a girl has a dream that she goes to church in her skimpy schoolgirl outfit. She kneels before a giant cross of Jesus to pray, and as a result Jesus comes alive. He pops out his nails, comes down from the cross and starts behaving passionately with her when she wakes up, quite startled by her dream.

3. We submit that the scene was within the ambit of the series that is known to include a number of unconventional sex scenes in dramatic form, such as this dream sequence.

4. The presence of the appropriate advisories allowed viewers the option of tuning out if they would be offended by scenes of sex, language or prejudicial scenes of a religious nature, as in this instance.

We submit that there has been no transgression of the Code.

'We submit that there has been no transgression of the Code' - the BCCSA was referring to the code of conduct that broadcasters in South Africa have to abide by. So, what code was being broken according to the pastor who lodged the complaint? Foucault is instructive here: 'If sex is repressed, that is, condemned to prohibition, nonexistence, and silence, then the mere fact that one is speaking about it has the appearance of a deliberate transgression (Foucault 1978:6).

We would argue that the fact that one is singing about a sexual relationship with the divine, may itself be the transgression, but it is an acceptable transgression since the sexual act is spiritualized as an act of worship - the ultimate form of devotion. However, that is as far as the church is willing to go. This is the enactment of an imminent God who literally stops 'hanging around' (as is seen in the scene) and comes down to love his 
worshipers or expresses desire for them, rather than becoming an indecency that is intolerable.

We would further submit that the lyrics of the songs sung in the services - 'Your friendship, it is intimate, I feel like moving to the rhythm of Your grace' or 'Hold me close, let your love surround me' - all find logical expression and conclusion in this scene from the series. The lyrics point to an intimate relationship with Jesus that is sung to the syntax of $R \& B$ popular love songs. What is it about this mutually consenting sexual relationship between the divine and a human that bothers the pastor who has lodged the complaint? The answer lies in the Puritan sexual ethic which governs his theology.

Our experiences of this Puritan sexual ethic can be best theoretically explained by Jaci Maraschin, who identifies the causes of sexual repression within two main areas: Trinitarian theology and Greek philosophy. In terms of trinitarian theology, he explains: 'Our Christian God has been pictured like that. He is a father but has no wife. He has a son but never experimented with an ejaculation. And the Spirit, who is an invisible and disembodied idea, has no body to be caressed or with which to embrace other bodies' (Maraschin 2006:174).

It is clear from our exploration of Pentecostal liturgical practices that, while Jesus is attributed the characteristics of a lover in the songs, and he can actually bring believers to symbolic orgasms under the guise of being 'slain in the spirit', there is little to no room for any consideration of a physical embodied encounter with this God.

Maraschin attributes this apparent disjuncture to the relationship of theology with Greek philosophy:

Both Greek philosophy and biblical theology invented the same dichotomy of body and spirit. This turned out to be a sinister Pandora's Box from which emerged all types of disgrace and evil. If our bodies are inferior and are constantly fighting against the spirit, we have the obligation to overcome them for the sake of our spirits...Christianity also created ascetic practices, often sacrificial, to help sinners to get rid of their bodies in order to enjoy a perfect 'spiritual life' (Maraschin 2006:172).

We would argue that, while in practice, the Black Holiness movements would dismiss the indecency thesis that we have offered in this essay, it is precisely 
in the Black Holiness Pentecostal movements that the search for a more embodied indecenting of theologies lies. Gallien (2011:118) summarizes four aspects of the movement that are important to this task:

1. Integration of body and soul.

2. Forms of worship that appeal to the head, heart, and hands.

3. Songs based on freedom and hope.

4. Performance orientation.

To imagine a mutually consenting sexual relationship between the divine and humans, means to reimagine heteronormative notions of sexuality - for the male Jesus does not just 'commune' with female believers - and the Jesus that comes down from this cross for such a relationship is not a married Jesus... and what of multiple partners? Can this sacred sex be safe sex? And for whom? This is the 'Pandora's box' that is opened when one starts to dare with these possibilities. The worshiping practices, in fact, serve as ample evidence of how the sexual abounds in the making of religious experience. Denying this, produces a denial of embodied experience with the divine, but it also shows a deliberate rejection of a more embodied indecenting of theologies. There is so much possibility for a more radical theology when the erotics between God and believer is not only recognized, but also cultivated. As Althaus-Reid (2000:7) argues:

The consequences of an analysis of sexual constructions carry important implications in any contextual theology. Basically they destabilise the sexual foundations of economic and political theories, and unveil the sexual ideology of systematic (even liberationist) theology. Theology is then seen in its true nature as being a sexual project from its epistemological foundation based on a sexed understanding of dualistic relationships and its legitimatory role.

\section{Conclusion}

Literature on Pentecostalism either documents its performances from an interpretive phenomenology of religions perspective, or more critical investigations usually disparage its excesses in terms of its unconventional healing and 
ecstatic worship practices. Equally, gender-critical studies on Pentecostalism have foregrounded the conservative nature of such theologies, focusing on Pentecostalism's fixation with doctrinal dualisms which enforce a separation of body and spirit, and a Puritan sexual ethic.

As we have shown in this essay, it was in Marvin Gaye's struggle to reconcile body and spirit that we have some insight to the possibility that Pentecostal liturgical performances hold for more holistic and life-giving sexualities and spiritualties. Steve Sullivan captures it perfectly in his entry on the song Let's get it on, in the Encyclopedia of great popular song recordings. Drawing on the work of Gerri Hirshey and David Ritz (his biographer), Sullivan writes:

With its seductive vibe and well-placed moans and screams, Let's Get it $\mathrm{On}$ is one of the most erotic records ever made. 'The singer is in a languorous rhythmic garden, and there's no evil in it,' writes Gerri Hirshey. 'Chastity doesn't stand a chance here, but still, it is a holy place. Serpent-soft, Gaye's voice wonders in a whisper whether the lady knows the meaning of being sanctified'... The song is about the union of love and sex; sex isn't wrong, he sings, 'if the love is true'. He was struggling to overcome his Pentecostal upbringing, and seeking the ultimate goal not of mere sexual satisfaction, but spiritual fulfilment. His growling and groaning, his shouts and whispers, were cries for understanding, not mere satiation... Gaye spent the last dozen years of his life 'trying to integrate his two strongest sources of emotional enthusiasm - God and sex' (Sullivan 2013:711).

Indeed, Marvin Gaye shows us the possibilities of a sanctified sexuality - one that is embodied and real and sexy. The tragedy of his death ironically opens up the possibilities to consider the sex-positive theologies that are uniquely available within Pentecostalism. The question is if we would dare to go there? Can we just 'get it on?' 


\section{References}

Althaus-Reid, M.M. 2000. Indecent theology. New York: Routledge.

Anderson, A. 2005. The origins of Pentecostalism and its global spread in the early twentieth century. Transformation 22, 3: 175-185.

Anderson, A. 2013. An introduction to Pentecostalism: Global charismatic Christianity. Cambridge: Cambridge University Press.

BCCSA (Broadcasting Complaints Commission of South Africa). 2015. Naidoo vs. SABC3. Available at: https://bccsa.co.za/wp-content/ uploads/2015/12/case-no-06-2015.pdf. (Accessed on 23 May 2019.)

Bethesda Worship Centre. 2017. Saturday night highlights (for people who work on Sunday). Service led by Pastor Trevor Subramoney. YouTube. Available at: https://www.youtube.com/watch?v=byUTRD-qgyQ. (Accessed on 25 January 2019.)

Burchardt, M. 2011. Challenging Pentecostal moralism: Erotic geographies, religion and sexual practices among township youth in Cape Town. Culture, health \& sexuality 13, 6: 669-683.

Californication. 2016. YouTube. Available at: https://www.youtube.com /watch? $\mathrm{v}=7 \mathrm{sRx}-6 \mathrm{uPml} 8$. (Accessed on 25 January 2019.)

Casting Crowns. 2003. Your love is extravagant. Anderson, J., P. Kipley \& P.C. Kipley (songwriters). Album. Available at: https://www.newreleasetoday.com/lyricsdetail.php?lyrics $\mathrm{id}=26747$. (Accessed on 25 January 2019.)

Creech, J. 1996. Visions of glory: The place of the Azusa Street revival in Pentecostal history. Church History 65, 3: 405-424.

Day, K.L. 2016. Religious resistance to Neoliberalism: Womanist and black feminist perspectives. New York: Palgrave Macmillan.

Foucault, P.-M. 1978. The history of sexuality. Vol. 1. An Introduction. Hurley, R. (trans.). New York: Pantheon.

Foucault, P.-M. 1980a. Two lectures. In Gordon, C. (ed.): Power/Knowledge: Selected interviews and other writings 1972-1977. New York: Harvester Wheatsheaf.

Foucault, P.-M. 1980b. Power/Knowledge: Selected writings and other interviews 1972-1977. Gordon, C. (ed). Gordon, C., L. Marshal, J. Mepham \& K. Soper (trans). New York: Pantheon. 
Foucault, P.-M. 1982. Afterword: The subject and power. In Dreyfus, H.L. \& P. Rabinow: Michel Foucault: Beyond Structuralism and hermeneutics. London: Harvester Wheatsheaf.

Foucault, P.-M. 1985. The use of pleasure: The history of sexuality. Vol 2. Hurley, R. (trans). New York: Vintage Books.

Foucault, P.-M. 1997a. Subjectivity and truth. In Rabinow, P. (ed.): Michel

Foucault: Ethics, subjectivity and truth. New York: The New Press.

Foucault, P.-M. 1997b. Technologies of the self. In Rabinow, P. (ed.): Michel

Foucault: Ethics, subjectivity and truth. New York: The New Press.

Foucault, P.-M. 1997c. Sex, power, and politics. In Rabinow, P. (ed.): Michel Foucault: Ethics, subjectivity and truth. New York: The New Press.

Fragar, R., G. Bullock \& D. Zschech 1992. The power of your love. Album. Available at: https://genius.com/Hillsong-worship-the-power-of-yourlove-lyrics. (Accessed on 25 January 2019.)

Gaither, W.J. 1963. He touched me. Album. Performed by Elvis Presley in 1971. Available at: https://www.lyrics.com/lyric/4672344/Gaither+Vocal+Band+\%26+The+Bill+Gaither+Trio/He+Touched+Me. (Accessed on 25 January 2019.)

Gallien, L.B. Jr. 2011. Crossing over Jordan: Navigating the music of heavenly bliss and earthly desire in the lives and careers of three twentieth-century African American holiness-pentecostal 'Crossover' Artists. In Yong, A. \& E.Y. Alexander (eds.): Afro-Pentecostalism: Black Pentecostal and charismatic Christianity in history and culture. New York: New York University Press.

Gaye, M. \& E. Townsend 1973. Let's get it on. Album. Available at: https://www.lyricsfreak.com/m/marvin+gaye/lets+get+it+on_2024457 2.html. (Accessed on 24 January 2019.)

Kalu, O.U. 2009. A discursive interpretation of African Pentecostalism. Fides et Historia 41, 1: 71-90.

Maraschin, J.C. 2006. Worship and the excluded. In Althaus-Reid, M. (ed.): Liberation theology and sexuality. Aldershot: Ashgate.

Mbembe, J.-A. 2001. Ways of seeing: Beyond the new nativism. Introduction. African Studies Review 44, 2: 1-14.

Phillips, L.E. \& T. Riches 2018. Pentecostal worship: Introduction. Liturgy 33, 3: $1-3$.

Sullivan, S. 2013. Encyclopedia of great popular song recordings. Vol. 1. Lanham: Scarecrow Press. 
Van Klinken, A.S. 2018. Citizenship of love: The politics, ethics and aesthetics of sexual citizenship in a Kenyan gay music video. Citizenship Studies 22, 6: 650-665.

Ware, F.L. 2011. On the compatibility/incompatibility of Pentecostal premillenialism with Black Liberation Theology. In Yong, A. \& E.Y. Alexander (eds.): Afro-Pentecostalism: Black Pentecostal and charismatic Christianity in history and culture. New York: New York University Press.

Sarojini Nadar Desmond Tutu South African Research Chair (SARChI) in Religion and Social Justice University of the Western Cape snadar@uwc.ac.za Johnathan Jodamus Department of Religion and Theology University of the Western Cape jjodamus@uwc.ac.za 